\title{
Region-specific emission factors for Brazil increase the estimate of nitrous oxide emissions from nitrogen fertiliser application by $21 \%$
}

Mancebo Mazzetto, Andre; Styles, David; Gibbons, James; Arndt, Claudia ; Misselbrook, T.; Chadwick, Dave

\section{Atmospheric Environment}

DOI:

10.1016/j.atmosenv.2020.117506

Published: 01/06/2020

Peer reviewed version

Cyswllt i'r cyhoeddiad / Link to publication

Dyfyniad o'r fersiwn a gyhoeddwyd / Citation for published version (APA):

Mancebo Mazzetto, A., Styles, D., Gibbons, J., Arndt, C., Misselbrook, T., \& Chadwick, D. (2020). Region-specific emission factors for Brazil increase the estimate of nitrous oxide emissions from nitrogen fertiliser application by $21 \%$. Atmospheric Environment, 230, [117506]. https://doi.org/10.1016/j.atmosenv.2020.117506

Hawliau Cyffredinol / General rights

Copyright and moral rights for the publications made accessible in the public portal are retained by the authors and/or other copyright owners and it is a condition of accessing publications that users recognise and abide by the legal requirements associated with these rights. study or research.

- Users may download and print one copy of any publication from the public portal for the purpose of private

- You may not further distribute the material or use it for any profit-making activity or commercial gain

- You may freely distribute the URL identifying the publication in the public portal ?

Take down policy

If you believe that this document breaches copyright please contact us providing details, and we will remove access to the work immediately and investigate your claim. 
1 Region-specific emission factors for Brazil increase the estimate of nitrous oxide

2 emissions from nitrogen fertiliser application by $21 \%$

3

4 Andre M. Mazzetto ${ }^{\mathrm{a}, \mathrm{b} *}$, David Styles ${ }^{\mathrm{a}}$, James Gibbons ${ }^{\mathrm{a}}$, Claudia Arndt ${ }^{\mathrm{c}}$, Misselbrook, T.; ${ }^{\mathrm{d}}$

$5 \quad$ Dave Chadwick ${ }^{\mathrm{a}}$

6

$7 \quad{ }^{a}$ School of Natural Sciences, Bangor University, Bangor, Wales, UK

$8 \quad \mathrm{~b}$ AgResearch, Lincoln, New Zealand

$9{ }^{\mathrm{c}}$ Centro Agronomico Tropical de Investigacion y Ensenanza (CATIE), Turrialba, Costa Rica

$10{ }^{\mathrm{d}}$ Rothamsted Research Centre, North Wyke, Okehampton, UK

$11 *$ Corresponding author (andre.mazzetto@agresearch.co.nz - +64 3489 9160)

12

13 The authors have no conflicts of interest to disclose. 


\section{Abstract}

15 The use of synthetic nitrogen fertilisers is one of the most important land management 16 practices proposed to improve crop and pasture productivity. The use of such fertilisers in 17 excess can lead to greenhouse gas (GHG) emissions, linked to climate change, as well as 18 ammonia $\left(\mathrm{NH}_{3}\right)$ emissions, linked to eutrophication and soil acidification.. This context is 19 especially important in Brazil, which is responsible for a significant share of the food 20 produced in the world. To assess the impact of the use of nitrogen fertilisers, we conducted a structured review of Brazilian studies on the emission of nitrous oxide $\left(\mathrm{N}_{2} \mathrm{O} ; 11\right.$ studies $)$ and ammonia volatilisation $\left(\mathrm{NH}_{3} ; 13\right.$ studies) from nitrogen fertiliser application. The current emission factors (EF) suggested by the IPCC for $\mathrm{N}_{2} \mathrm{O}$ and $\mathrm{NH}_{3}(1$ and $11 \%$, respectively) are

24 lower than the mean values we found in our review (1.12 and 19\%, respectively). Our results showed that non-urea fertilisers (ammonium nitrate or ammonium sulphate) had a lower emission factor (EF) for $\mathrm{N}_{2} \mathrm{O}$ (1.07 and $0.60 \%$, respectively) and $\mathrm{NH}_{3}$ (3.17 and $14 \%$, respectively) in comparison with urea. The use of nitrification and urease inhibitors resulted in a reduction of the EFs of $\mathrm{N}_{2} \mathrm{O}\left(74 \%\right.$ lower) and $\mathrm{NH}_{3}$ (43\% lower) when compared with the Urea EF. Urea is the most common fertiliser used in Brazil, and the change for non-urea fertilisers or the use of inhibitors could lead to a reduction of $23 \%$ in the total $\mathrm{N}_{2} \mathrm{O}$ inventory.

31 The use of the new region-specific EFs results in an increase of $21 \%$ in the final $\mathrm{N}_{2} \mathrm{O}$

32 emission inventory.

34 Keywords: nitrous oxide, emission factor, Brazil, ammonia, synthetic fertiliser 


\section{Introduction}

The global demand for food due to human population growth and changing diets is putting pressure on the efficiency and sustainability of food production systems (Conijn et al., 2018). The increased use of land, pesticides and nutrients has played an important role in increasing agricultural production and delivering food security for many nations during the Green revolution, but these gains have been accompanied by negative impacts on the environment, especially greenhouse gas (GHG) (Davis et al., 2016) and ammonia $\left(\mathrm{NH}_{3}\right)$ emissions (Steffen et al., 2015), as well as nitrate leaching (Wang et al., 2019). The current challenge faced by the agricultural sector is to further increase production, while at the same time reducing or mitigating the environmental impacts. The pressure for food production will increase even further in the next decade (Calicioglu et al., 2019), and the potential for increasing productivity relies on relatively few areas. Currently, Brazil is responsible for $14 \%$ of beef, $12 \%$ of poultry, $41 \%$ of sugarcane and $30 \%$ of coffee exports (FAOStat, 2018). The Brazilian food system needs to be re-engineered to address future demand, and sustainable intensification is one promising strategy for the region.

"Sustainable intensification" is linked to the concept of agricultural efficiency (producing more per unit of input or maintaining production with less input - FAO, 2004), merged with the concept of sustainability, that considers the impact of practices on environmental, social and economic sectors (Garnett et al., 2013; Pretty, 2018). Among the concerns on the environment are GHG emissions (causing climate change and putting extrapressure on food production in Brazil). In the context of sustainable intensification, the optimal use of synthetic $\mathrm{N}$ fertilisers, and effective recycling of livestock manures, on crops and grassland will be important (Bouwman et al., 2013). Ammonia emissions are associated with environmental impacts such as eutrophication and soil acidification (Fowler et al., 2013), as 
well as effects on human health associated with the formation of fine particulates (Stokstad et al., 2014). Ammonia emissions also represent an indirect form of $\mathrm{N}_{2} \mathrm{O}$ loss (IPCC, 2006).

In order to assess the sustainability of food production in Brazil, it is imperative that the data employed to estimate these environmental impacts are as accurate as possible, to reliably underpin mitigation policies and management strategies. Improved estimations using robust key emission factors would support more accurate inventories and carbon footprints and help to target effective mitigation practices. Currently, $\mathrm{N}_{2} \mathrm{O}$ emission and $\mathrm{NH}_{3}$ volatilisation in Brazil are estimated by the IPCC Tier 1 method (using a single default emission factor expressed as a fraction of the $\mathrm{N}$ applied to the soil), based on Bouwman (1996). The limitations of such an approach are that the same emission factor $(\mathrm{EF})$ is used irrespective of the fertiliser type, soil type, land use (arable or grass), and different climates throughout Brazil. The synthesis of appropriate data would provide a much-needed improvement over the current IPCC Tier 1 approach, leading to an inventory that reflects the region's fertiliser management practices, soils and climate. This paper focusses on direct $\mathrm{N}_{2} \mathrm{O}$ and $\mathrm{NH}_{3}$ fluxes and emission factors derived from synthetic fertiliser inputs to agricultural systems. The main goal of this paper is to review the available literature and define region-specific emission factors applicable to the Brazilian conditions to better understand the sensitivity of the choice of EFs used in the Brazilian GHG inventory.

\section{Materials and methods}

We performed a systematic literature review focusing on direct $\mathrm{N}_{2} \mathrm{O}$ emission and $\mathrm{NH}_{3}$ volatilisation in Brazil. The literature search was performed using "Web of Science", "Science Direct", "Scielo" and "Google Scholar" search engines. The search was carried out using all combinations of the following keywords (and their translations in Portuguese): "nitrous oxide", "ammonia", and "fertiliser". The resulting reference lists of publications were screened and 


.

retained if they met the following criteria: (1) published in peer-reviewed journals; (2) performed in Brazil; (3) not conducted in greenhouses or manipulated weather conditions. After discarding publications that did not meet the criteria, the final database for analysis included 11 papers for $\mathrm{N}_{2} \mathrm{O}(\mathrm{n}=63$ experiments $)$ and 13 papers for $\mathrm{NH}_{3}(\mathrm{n}=83$ experiments $)$ (databases available in the Supporting Information).

For each retained publication, a specific study code was assigned and the following characteristics were recorded in the database: authors, year, region, latitude, longitude, elevation (m.a.s.l.), Koppen-Geiger climatic classification, annual rainfall (mm), average annual temperature $\left({ }^{\circ} \mathrm{C}\right)$, soil type, crop or pasture genus, number of treatments, number of replications, season, $\mathrm{N}$ fertiliser type, application method and rate, cumulative $\mathrm{N}_{2} \mathrm{O}$ emissions ( $\left.\mathrm{kg} \mathrm{N}_{2} \mathrm{O}-\mathrm{N} \mathrm{ha}^{-1}\right)$, cumulative $\mathrm{NH}_{3}$ volatilisation $\left(\mathrm{kg} \mathrm{NH}_{3}-\mathrm{N} \mathrm{ha}^{-1}\right)$ and emission factors (EF). The most common missing data in reviewed papers were related to climate characteristics. These gaps were filled where necessary using data from the nearest weather station (based on the location information provided in the paper). When the EF was not reported in the study, we derived it according to Eq 1. We used the software WebPlotDigitizer to extract precise numbers when data were presented only as figures.

$$
E F(\%)=\left(\frac{\text { EmissionFT }- \text { EmissionC }}{\text { Applied fert }}\right) * 100
$$

3

\section{Where:}

$\mathrm{EF}(\%)=$ Emission Factor, in $\%$;

6 EmissionFT $=$ Emission or volatilisation from fertiliser treatment $\left(\right.$ in $\mathrm{kg} \mathrm{N} \mathrm{ha}^{-1} \mathrm{year}^{-1}$ );

EmissionC $=$ Emission or volatilisation from control treatment $\left(\right.$ in $\left.\mathrm{kg} \mathrm{N} \mathrm{ha}^{-1} \mathrm{year}^{-1}\right)$;

Applied fert: Amount of fertiliser applied (in $\mathrm{kg} \mathrm{N} \mathrm{ha}^{-1} \mathrm{year}^{-1}$ ). 
110 Due to the lack of statistical information reported in some studies (standard deviation,

111 coefficient of variation, $p$-value, etc.), we were not able to perform a formal meta-analysis.

112 Descriptive statistics were calculated for each variable (mean, minimum, maximum, range,

113 standard deviation and coefficient of variation). To account for the precision of each study, the

114 number of samples described in each paper was used as a weighting factor (studies with more

115 replicates were assigned greater importance). One-way and two-way ANOVA were then used

116 to investigate the structural relationship between the responses, testing the $\mathrm{N}_{2} \mathrm{O}$ emissions

117 against the soil type, soil texture and land use. All statistical differences were checked to

$118 p<0.05$, but we were not able to find statistical differences. Pearson's correlation coefficient

119 was calculated. All statistical analyses were performed using R (R Core Studio, 2018).

120 We consulted the FAO databases (FAOStat, 2018) to estimate the total annual quantity

121 of $\mathrm{N}$ fertiliser used in Brazil. Based on the data available, we derived estimates for total $\mathrm{N}_{2} \mathrm{O}$

122 emission, $\mathrm{NH}_{3}$ volatilisation and $\mathrm{NO}_{3}{ }^{-}$leaching (summing the direct $\mathrm{N}_{2} \mathrm{O}$ emission with the

123 indirect emission from $\mathrm{NH}_{3}$ volatilisation and $\mathrm{NO}_{3}{ }^{-}$leaching - Supplementary ) using the IPCC

124 Tier 1 EFs and the new region-specific EFs derived from this review for direct $\mathrm{N}_{2} \mathrm{O}$ and $\mathrm{NH}_{3}$.

125 (Table 1).

126

\section{Results}

\subsection{Literature evaluation}

Most of the papers are from the Central-South region of the country (latitudes $23^{\circ}$ to

$13010^{\circ} \mathrm{S}$ ), in a transition from tropical to subtropical climates. For the $\mathrm{N}_{2} \mathrm{O}$ database, $20 \%$ of the

131 papers did not report the EF, carbon content or bulk density of the soil, only $10 \%$ reported the soil ammonium $\left(\mathrm{NH}_{4}{ }^{+}\right)$and nitrate $\left(\mathrm{NO}_{3}^{-}\right)$content and 30\% reported crop yield. Other factors

133 were reported more frequently, including soil texture and classification (90\% of the papers),

134 soil $\mathrm{pH}$ and duration of the experiment (100\% of the papers). A similar scenario was found for 
135 the $\mathrm{NH}_{3}$ database, where soil texture (70\%), soil classification (90\%), soil $\mathrm{pH}$ and experiment duration (100\%) were often reported, while crop yield and bulk density were reported in only $10 \%$ of the papers. Soil $\mathrm{NH}_{4}{ }^{+}$or $\mathrm{NO}_{3}{ }^{-}$content were not reported in any paper. The average duration of the experiments was 188 and 55 days for $\mathrm{N}_{2} \mathrm{O}$ and $\mathrm{NH}_{3}$, respectively, and the average fertiliser application rate was 127 and $92 \mathrm{~kg} \mathrm{~N} \mathrm{ha}^{-1}$ for $\mathrm{N}_{2} \mathrm{O}$ and $\mathrm{NH}_{3}$, respectively.

\section{2 $\mathrm{N}_{2} \mathrm{O}$ emission and $\mathrm{EF}$}

The $\mathrm{N}_{2} \mathrm{O}$ emission was positively correlated with the fertiliser application rate $(\rho=0.55)$, soil texture (sand content, $\rho=0.27)$ and $\mathrm{pH}(\rho=0.25)$, and the $\mathrm{N}_{2} \mathrm{O} E F$ was negatively correlated with the soil bulk density $(\rho=-0.60)$. The EF ranged from $0.01 \%$ to $6.70 \%$, and $75 \%$ of the EFs reported (or calculated) were in the range given by the IPCC for the Tier 1 default EF $(0.30 \%$ to $3 \%$, mean $1 \%$ - IPCC, 2019). Overall, the average $\mathrm{N}_{2} \mathrm{O}-\mathrm{EF}$ was $1.12 \%$ (95\% confidence Interval $=0.75$ to $1.48 \%$; median $=0.78 \%$ ). Fertiliser type influenced the final $\mathrm{EF}$, with a higher value found when using urea $(1.45 \%)$, and a lower when using ammonium sulphate $(0.60 \%)$

(Figure 1). Lower EFs were found when using nitrification inhibitors (NI) and coated urea

150 (CU), reducing the average urea EF by $74 \%$ and $61 \%$, respectively, with results lower than the average IPCC EF (Figure 1). The mean EF for the Oxisols was lower than the IPCC Tier 1 default, independent of the fertiliser type, while for other soil types (Ultisol and NonClassified) the EFs were higher than the IPCC Tier 1 default (Figure 2), although there were very few data for Ultisols. The effect of the NI was greater on the Oxisol (86\%) (Figure 2). Soil texture influenced the final EF, with lower values found on loam and sandy clay loam soils than on sandy loam soils (Figure 3). Land use also influenced EF, with results lower than the IPCC average for pastures (Brachiaria and Pennisetum) and higher higher than the IPCC average for crops (Saccharum and Zea) (Figure 4). 


\section{$3.3 \mathrm{NH}_{3}$ volatilisation and $\mathrm{EF}$}

Cumulative $\mathrm{NH}_{3}$ volatilisation was negatively correlated with soil $\mathrm{pH}$ and rainfall $(\rho=$ -0.23 and -0.40 , respectively) and positively correlated with the fertiliser application rate $(\rho=$ $0.39)$, while the $\mathrm{NH}_{3} \mathrm{EF}$ was negatively correlated with temperature $(\rho=-0.30)$. The EFs ranged from 0 to $59 \%$, Overall, the average $\mathrm{NH}_{3}$-EF was $19 \%$ (median = 18\%), higher than the IPCC default Tier 1 Frac ${ }_{\mathrm{GASF}}$ value of $11 \%$ (IPCC, 2019). Fertiliser type influenced the final EF, with a higher value found when using urea $(1.45 \%)$, and a lower value when using non-urea, i.e., ammonium sulphate $(0.60 \%)$ and ammonium nitrate (1.07\%) (Figure 1). Lower EFs were found when using urease inhibitors (UI) and coated urea (CU), reducing the average urea EF by 43 and 34\%, respectively, when compared with the Urea EF (Figure 1). Soil type and land use had no influence on the final EF (Figure 2 and 4), but we found soil texture resulted in significant differences $(\mathrm{p}<0.05)$, with lower EFs for loam and sandy clay loam soils than on sandy loam soils (Figure 3).

\subsection{N fertiliser emission budget}

The most common fertiliser used in Brazil is urea (52\%), followed by ammonium nitrate (11\%) and ammonium sulphate (10\%), accounting for $73 \%$ of the total $\mathrm{N}$-fertiliser used in the country (FAOstats 2018, Table 1 - Supplementary Information). The remainder of the $\mathrm{N}$ fertiliser $(27 \%)$ is compound fertiliser, i.e. $\mathrm{N}$ in combination with phosphorus $(\mathrm{P})$ and potassium (K) (e.g. potassium nitrate, sodium nitrate, NPK, etc). When applying the mean EFs derived from this study by fertiliser type for Brazil, the total $\mathrm{N}_{2} \mathrm{O}-\mathrm{N}$ emission budget increased by $21 \%$ compared with the IPCC Tier 1 EF (Figure 5 and Supplementary Information Table 1). This was mostly associated with revisions to the $\mathrm{N}_{2} \mathrm{O}$ and $\mathrm{NH}_{3} \mathrm{EFs}$ for urea, with increases in the emission estimates of $45 \%$ and $73 \%$, respectively, compared with using the IPCC Tier 1 default EF. If all the urea applied in Brazil were to be treated with a nitrification and urease 
185

186

187

188

189

190

191

192

193

194

195

196

197

198

199

200

201

202

203

204

205

206

207

208

209

inhibitor (Figure 5), the $\mathrm{N}_{2} \mathrm{O}-\mathrm{N}$ emission for urea use would decrease by $43 \%$, resulting in a final emission budget $23 \%$ lower than the current estimate using the IPCC Tier 1 default EFs (Figure 5).

\section{Discussion}

As recommended by Buckingham et al. (2014) and Gilsanz et al. (2016), we strongly advise researchers to follow standard protocols describing the data and adhere to a minimum reporting requirement so that the data can be used by future meta-analyses (Buckingham et al., 2014). More conclusions could have been drawn from this review if the authors of previous studies had systematically reported important data, such as soil $\mathrm{NO}_{3}{ }^{-}$and $\mathrm{NH}_{4}{ }^{+}$content, bulk density, soil carbon and crop yield. Furthermore, only three studies analysed both $\mathrm{N}_{2} \mathrm{O}$ emission and $\mathrm{NH}_{3}$ volatilisation (da Silva Paredes et al., 2014; Martins et al., 2015 and Martins et al., 2017). More research that focusses on nitrogen use efficiency and multiple pathways of $\mathrm{N}$ loss is necessary to provide a more complete understanding of the fate of $\mathrm{N}$ inputs in tropical systems. The conclusions drawn from this review are limited by the number of studies available in Brazil.

The range of EFs reported or derived from the literature reflect the variability in emissions across different $\mathrm{N}$ sources, different soil types and different land uses, leading to high uncertainty (Figures 1 to 4). The average EF for direct $\mathrm{N}_{2} \mathrm{O}$ emission (across all fertiliser types, application rates, soils) in this study was $1.12 \%$, similar to the new 2019 IPCC Tier 1

default. A recent study in the UK showed similar results for fertiliser applications to grassland $(\mathrm{EF}=1.12 \%$ - Cardenas et al., 2019), while a study in New Zealand reported lower values (0.60\% - van der Weerden et al., 2016). The average emission factor for $\mathrm{NH}_{3}$ volatilisation was $19 \%$, which is $72 \%$ higher than the IPCC default value (11\%), but similar to the global average 
210 of $18 \%$ found by Pan et al (2016). Non-urea fertilisers (ammonium nitrate and ammonium

211 sulphate) had lower EFs for both $\mathrm{N}_{2} \mathrm{O}$ and $\mathrm{NH}_{3}$ (Figure 1). In contrast, Harty et al. (2016)

212 reported that changing the $\mathrm{N}$ fertiliser source from calcium ammonium nitrate to urea leads to

213 a reduction from 58 to $87 \%$ in the direct $\mathrm{N}_{2} \mathrm{O}-\mathrm{EF}$. From our study, we show that the non-urea

214 fertilisers have, on average, a $61 \%$ lower $\mathrm{N}_{2} \mathrm{O}-\mathrm{EF}$ than urea fertilisers (Figure 1).

215 Tropical conditions (humid and warm soil) favour rapid urea hydrolysis, increasing

216 the rate of $\mathrm{NH}_{3}$ volatilisation (Sommer et al., 2004). The soil $\mathrm{pH}$ observed was generally low,

217 ranging from 4.20 to 6.20 (especially in Oxisols, average $\mathrm{pH} 4.5$ ). In such conditions,

218 nitrification is inhibited, limiting $\mathrm{NO}_{3}{ }^{-}$formation and $\mathrm{N}_{2} \mathrm{O}$ emissions (Mørkved et al., 2007)

219 (Figure 2). In our study, even in soils with low $\mathrm{pH}$, urea showed the higher $\mathrm{N}_{2} \mathrm{O}$ EF (Figure

220 2). Urea application generates localised zones of higher $\mathrm{pH}$, which drives $\mathrm{NH}_{3}$ volatilisation

221 but also favours nitrification and $\mathrm{NO}_{3}{ }^{-}$formation and consequently, $\mathrm{N}_{2} \mathrm{O}$ emissions (Wang et

222 al., 2018). Clay content has been identified as one of the main edaphic factors controlling the

$223 \mathrm{~N}_{2} \mathrm{O}$ EF (Wang et al., 2018), with EFs decreasing exponentially with increasing soil clay

224 content due to a reduction in gas diffusivity, promoting $\mathrm{N}_{2} \mathrm{O}$ reduction to $\mathrm{N}_{2}$ through

225 denitrification (Gu et al., 2013). This may explain the lower $\mathrm{N}_{2} \mathrm{O}$ EF for clay and loam soils

226 (Figure 3) and Oxisols (which have a higher clay content than Ultisols, Figure 2) in this

227 review. The low $\mathrm{N}_{2} \mathrm{O}$ EF found on tropical pastures (Figure 4) may be related to biological

228 nitrification inhibition (BNI), a well-known process common in Brachiaria pastures

229 (Subbarao et al., 2009). Compounds exuded from the roots of some Brachiaria species inhibit

230 the nitrification process, consequently reducing the emission of $\mathrm{N}_{2} \mathrm{O}$ and leaching of $\mathrm{NO}_{3}{ }^{-}$.

231 (Arango et al., 2014).

232 Our review showed that the use of nitrification and urease inhibitors resulted in lower

233 EFs for $\mathrm{N}_{2} \mathrm{O}$ and $\mathrm{NH}_{3}\left(74 \%\right.$ and $43 \%$, respectively, Figure 1), leading to a lower $\mathrm{N}_{2} \mathrm{O}$ emission

234 budget when compared with the budget calculated using the 2019 IPCC EFs (Figure 5). This 
agrees with reports from studies in temperate climates (Cameron et al., 2014; Abalos et al., 2014 Misselbrook et al., 2014; Li et al., 2017). Ammonia volatilisation was also reduced with the use of urease inhibitors, similar to what has been found in temperate climates (Pan et al., 2016). The use of nitrification inhibitors results in a lower nitrification rate, allowing more time for the plants to absorb the applied $\mathrm{NH}_{4}{ }^{+}$, but at the same time can stimulate more $\mathrm{NH}_{3}$ volatilisation (Soares et al., 2012, Abalos et al., 2014). Other factors, such as runoff and soil moisture content (due to more rainfall) and a quicker metabolism of the soil biomass (due to higher temperature in the tropics) also affects the $\mathrm{N}$ dynamics in tropical soils (Akiyama et al., 2000). The use of inhibitors can potentially improve the $\mathrm{N}$ use efficiency of fertilisers, leading to lower agronomic losses. Other studies have shown that the use of inhibitors can reduce $\mathrm{NO}_{3}{ }^{-}$ leaching losses (Monaghan et al., 2013), increase plant assimilation of $\mathrm{NH}_{4}^{+}$(Akiyama et al., 2013), and increase crop/pasture yield (depending on the combination of inhibitor and cropping systems) (Abalos et al., 2014; Li et al., 2017). Urea is the most common fertiliser in Brazil due to its $\mathrm{N}$ content (46\%), having a high density of $\mathrm{N}$ at a low cost. The use of non-urea fertilisers could lead to lower total GHG emissions (Figure 5). An important factor to consider is the impact on farmer costs due to the higher price of more efficient fertilisers and inhibitors in comparison with urea (Rose et al., 2018). The adoption of such technologies voluntarily will depend on products affordability for farmers, which may,, in turn, depend on subsidy interventions (Tzemi and Breen, 2019). According to Carswell et al. (2018), there is no economic incentive for the farmer to use lower environmental impact option unless externality costs are incorporated into fertiliser prices. Another possible mitigation option is the subsurface application/incorporation of urea-based $\mathrm{N}$ fertiliser, which can reduce the $\mathrm{NH}_{3}$ volatilisation by $63 \%$ (Huang et al., 2016). In our study, all the experiments reviewed applied the fertiliser to the soil surface (most manually). Management techniques such as splitting the 
fertiliser application can potentially reduce $\mathrm{N}_{2} \mathrm{O}$ emission (Bell et al., 2015; Cardenas et al., 2019; Borges et al., 2019) and $\mathrm{NH}_{3}$ volatilisation (Huang et al., 2016).

The $\mathrm{N}_{2} \mathrm{O}$ budget calculated for Brazil in this paper represents the best estimate of the $\mathrm{N}_{2} \mathrm{O}$ emission using the currently available data, including uncertainties, especially regarding $\mathrm{NO}_{3}{ }^{-}$leaching factors (not reviewed in this study) that precede indirect $\mathrm{N}_{2} \mathrm{O}$ emissions. In our review, all the experiments evaluating $\mathrm{NH}_{3}$ volatilisation used chamber-methods. As pointed out by Jiang et al. (2017), chamber methods can over-or-underestimate the final emissions, depending on the difference in temperature, humidity and airflow within and outside the chamber. To develop EFs for use in emission inventories or farm/regional scale budgets, appropriate micrometeorological methods should be used which do not influence the emission (e.g. Denmead et al., 1993; Flesch et al., 2005; Misselbrook et al., 2005). Chamber studies can give useful comparative information on influencing factors and the efficacy of potential mitigation methods (Chambers and Dampney, 2009), which may be used to inform empirical or process-based models to derive EF though such models should be evaluated against micrometeorological datasets. Further studies in a wider range of Brazil are necessary to properly evaluate EFs across highly variable climate and soils in the country. Revised $\mathrm{NH}_{3}$ emission factors could also inform more accurate environmental footprints for food products in Brazil, especially livestock products, in other environmental impact categories, such as eutrophication and acidification (Leip et al., 2015).

\section{Conclusion}

Our results showed that non-urea fertilisers had a lower EF for $\mathrm{N}_{2} \mathrm{O}$ and $\mathrm{NH}_{3}$ in comparison with urea. When nitrification or urease inhibitors were used, the final $\mathrm{N}_{2} \mathrm{O}-\mathrm{EF}$ and $\mathrm{NH}_{3}$-EF from urea was significantly reduced. Based on our estimation, the complete budget of $\mathrm{N}_{2} \mathrm{O}$ emission (direct and indirect) using the IPCC Tier 1 approach is $61,442 \mathrm{Mg}$ 
$284 \mathrm{~N}_{2} \mathrm{O}$ (for the year 2016). Use of the region-specific direct $\mathrm{N}_{2} \mathrm{O}$ and $\mathrm{NH}_{3}$ EFs increases this

$285 \mathrm{~N}_{2} \mathrm{O}$ emission budget to 74,638 for the same year. This region-specific estimation would be

286 reduced by $23 \%$ if all urea used in Brazil were incorporated with nitrification and urease

287 inhibitors. Management practices such as the sub-surface application of $\mathrm{N}$ fertiliser could

288 further reduce the impact of the fertiliser applications. When possible, specific policies

289 should aim to reduce the price of, and/or provide subsidies for non-urea fertilisers or

290 inhibitor-treated urea, given that at the current market prices most farmers would prefer to

291 purchase urea.

We recognise that our results are limited by the number and geographic locations of

293 the published studies that met our selection criteria for inclusion in the analysis. Further

294 research on agricultural $\mathrm{N}$ loss pathways in Brazil should be prioritised since this is an 295 important country for global food production. Given the current trends in food demand and

296 the pressure for reducing deforestation, sustainable intensification on current grassland and

297 cropland in Brazil will be necessary, where best management practices for fertiliser use are

298 adopted to improve $\mathrm{N}$ use efficiency and minimize $\mathrm{N}$ losses.

299

300 Acknowledgements

301 This study was conducted as part the project "Sustainable futures for the Costa Rica dairy

302 sector: optimising environmental and economic outcomes" (BB/P023150/1), funded through

303 the UK's Biotechnology and Biological Sciences Research Council (BBSRC), via the Global

304 Challenge Research Fund (GCRF). We also acknowledge the financial support provided by

305 the Welsh Government and Higher Education Funding Council for Wales through the Sêr

306 Cymru National Research Network for Low Carbon, Energy and Environment (NRN-LCEE).

307 We thank Prof R. Brook for his valuable comments and suggestions in the earlier versions of 308 the manuscript. 
310 Contributions

311 A.M.M. built both databases, J.G. and A.M.M. performed the statistical analysis and

312 calculated the Emission factors and the Brazilian $\mathrm{N}_{2} \mathrm{O}$ budget; A.M.M. wrote the manuscript

313 in close collaboration with D.C., C.A., J.G. and D.S. All the authors discussed the results and

314 provided input to the manuscript. 


\section{References}

Abalos, D., Jeffery, S., Sanz-Cobena, A., Guardia, G., \& Vallejo, A. 2014. Meta-analysis of the effect of urease and nitrification inhibitors on crop productivity and nitrogen use efficiency. Agr Ecosyst Environ. 189, 136-144.

Arango, J., Moreta, D., Nunes, J., Hartmann, K., Domingues, M., Ishitani, M., Miles, J., Subbarao, G., Peters, M., Rao, I. 2014. Developing methods to evaluate phenotypic variability in biological nitrification inhibition (BNI) capacity of Brachiaria grasses. Trop Grasslands. 2, 6-8.

Bell, M. J., Hinton, N., Cloy, J. M., Topp, C. F. E., Rees, R. M., Cardenas, L., Chadwick, D. R. 2015. Nitrous oxide emissions from fertilised UK arable soils: fluxes, emission factors and mitigation. Agr Ecosyst Environ. 212, 134-147.

Borges, C. D., Carvalho, J. L. N., Kölln, O. T., Sanches, G. M., Silva, M. J., Castro, S. G. Q., Franco, H. C. J. 2019. Can alternative N-fertilization methods influence GHG emissions and biomass production in sugarcane fields? Biomass Bioenerg. 120, 21-27.

Bouwman, L., Goldewijk, K. K., Van Der Hoek, K. W., Beusen, A. H., Van Vuuren, D. P., Willems, J., Rufino, M. C., and Stehfest, E. 2013. Exploring global changes in nitrogen and phosphorus cycles in agriculture induced by livestock production over the 1900-2050 period, P. Natl. Acad. Sci. USA, 110, 20882-20887.

Bouwman, A.F. 1996. Direct emission of nitrous oxide from agricultural soils. Nutr. Cyc. Agroecosys. 46, 5370

Buckingham, S., Anthony, S., Bellamy, P. H., Cardenas, L. M., Higgins, S., McGeough, K., Topp, C. F. E. 2014. Review and analysis of global agricultural N2O emissions relevant to the UK. Sci Total Environ. 487, 164-172.

Calicioglu, O., Flammini, A., Bracco, S., Bellu, L., Sims, R. 2019. The future challenges of food and agriculture: an integrated analysis of trends and solutions. Sustainability-basel. 222, 1-21.

Cameron, K. C., Di, H. J., Moir, J. L. 2014. Dicyandiamide (DCD) effect on nitrous oxide emissions, nitrate leaching and pasture yield in Canterbury, New Zealand. New Zeal J Agr Res. 57, 251-270.

Cardenas, L. M., Bhogal, A., Chadwick, D. R., McGeough, K., Misselbrook, T., Rees, R. M., Calvet, S. 2019. Nitrogen use efficiency and nitrous oxide emissions from five UK fertilised grasslands. Sci Total Environ. 661, 696-710.

Chambers B., Dampney P. 2009. Nitrogen efficiency and ammonia emissions from urea-based and ammonium nitrate fertilisers. In: Prds International Fertiliser Society (no. 657). York: International Fertiliser Society. p. 120.

Conijn, J. G., Bindraban, P. S., Schröder, J. J., Jongschaap, R. E. E. 2018. Can our global food system meet food demand within planetary boundaries? Agr Ecosyst Environ. 251, 244-256.

da Silva Paredes, D., Lessa, A. C. da R., de Sant'Anna, S. A. C., Boddey, R. M., Urquiaga, S., Alves, B. J. R. 2014. Nitrous oxide emission and ammonia volatilization induced by vinasse and $\mathrm{N}$ fertilizer application in a sugarcane crop at Rio de Janeiro, Brazil. Nutr Cycl Agroecosystems. 98, 41-55.

Davis, K. F., Gephart, J. A., Emery, K. A., Leach, A. M., Galloway, J. N., D’Odorico, P. 2016. Meeting future food demand with current agricultural resources. Global Environ Chang. 39, 125-132.

Denmead, O.T. 1983. Micro-meteorological methods for measuring gaseous losses of nitrogen in the field. In: Gaseous Loss of Nitrogen from Plant-Soil Systems (eds J.R. Freney \& J.R. Simpson), pp. 133- 158. Martinus Nijhoff/Dr. W. Junk, The Hague.

Di, H. J., Cameron, K. C. 2016. Inhibition of nitrification to mitigate nitrate leaching and nitrous oxide emissions in grazed grassland: a review. J Soil Sediment. 16, 1401-1420. 
Food and Agriculture Organization of the United Nations. FAOSTAT Statistical Database. [Rome] :FAO, 2018.

Flesch, T. K., Wilson, J. D., Harper, L. A. 2005. Deducing Ground-to-Air Emissions from Observed Trace Gas Concentrations: A Field Trial with Wind Disturbance. J Appl Meteorol, 44, 475-484.

Garnett, T., Appleby, M. C., Balmford, A., Bateman, I. J., Benton, T. G., Bloomer, P., Godfray, H. C. J. 2013. Sustainable Intensification in Agriculture: Premises and Policies. Science. 341, 33-34.

Gilsanz, C., Báez, D., Misselbrook, T. H., Dhanoa, M. S., Cárdenas, L. M. 2016. Development of emission factors and efficiency of two nitrification inhibitors, DCD and DMPP. Agr Ecosyst Environ. 216, 1-8.

Gu, J., Nicoullaud, B., Rochette, P., Grossel, A., Hénault, C., Cellier, P., Richard, G. 2013. A regional experiment suggests that soil texture is a major control of $\mathrm{N}_{2} \mathrm{O}$ emissions from tile-drained winter wheat fields during the fertilization period. Soil Biol Biochem. 60, 134-141.

Harty, M. A., Forrestal, P. J., Watson, C. J., McGeough, K. L., Carolan, R., Elliot, C., Lanigan, G. J. 2016. Reducing nitrous oxide emissions by changing $\mathrm{N}$ fertiliser use from calcium ammonium nitrate (CAN) to urea based formulations. Sci Total Environ. 563, 576-586.

Huang, S., Lu, W., Bloszies, S., Shi, Q., Pan, X., and Zeng, Y. 2016. Effects of fertilizer management practices on yield-scaled ammonia emissions from croplands in China: a meta-analysis. Field Crops Res. 192, 118-125.

IPCC, 2019. 2019 Refinement to the 2006 IPCC Guidelines for National Greenhouse Gas Inventories. Volume 4, Chapter 11.

Jiang, Y., Deng, A., Bloszies, S., Huang, S., \& Zhang, W. 2017. Nonlinear response of soil ammonia emissions to fertilizer nitrogen. Biol Fert Soils. 53, 269-274.

Leip, A., Billen, G., Garnier, J., Grizzetti, B., Lassaletta, L., Reis, S., Simpson, D., Sutton, M.A., de Vries, W., Weiss, F., Westhoek, H. 2015. Impacts of European livestock production: nitrogen, sulphur, phosphorus and greenhouse gas emissions, land use water eutrophication and biodiversity. Environ Res Lett. 10, 1-13.

Martins, M.R., Jantalia, C. P., Polidoro, J. C., Batista, J. N., Alves, B. J. R., Boddey, R. M., Urquiaga, S. 2015. Nitrous oxide and ammonia emissions from $\mathrm{N}$ fertilization of maize crop under no-till in a Cerrado soil. Soil Till Res. $151,75-81$.

Martins, M.R., Sant'Anna, S.A.C., Zaman, M., Santos, R. C., Monteiro, R. C., Alves, B. J. R., Urquiaga, S. 2017. Strategies for the use of urease and nitrification inhibitors with urea: Impact on $\mathrm{N}_{2} \mathrm{O}$ and $\mathrm{NH}_{3}$ emissions, fertilizer$15 \mathrm{~N}$ recovery and maize yield in a tropical soil. Agr Ecosyst Environ. 247, 54-62.

Misselbrook, T. H., Cardenas, L. M., Camp, V., Thorman, R. E., Williams, J. R., Rollett, A. J., Chambers, B. J. 2014. An assessment of nitrification inhibitors to reduce nitrous oxide emissions from UK agriculture. Environ Res Lett. 9, 115006

Misselbrook, T. H., Nicholson, F. A., Chambers, B. J., Johnson, R. A. 2005. Measuring ammonia emissions from land applied manure: an intercomparison of commonly used samplers and techniques. Environ Pollut. 135, 389397.

Monaghan, R. M., Smith, L. C., de Klein, C. A. M. 2013. The effectiveness of the nitrification inhibitor dicyandiamide (DCD) in reducing nitrate leaching and nitrous oxide emissions from a grazed winter forage crop in southern New Zealand. Agr Ecosyst Environ. 175, 29-38.

Mørkved, P. T., Dörsch, P., Bakken, L. R. 2007. The $\mathrm{N}_{2} \mathrm{O}$ product ratio of nitrification and its dependence on long-term changes in soil pH. Soil Biol Biochem. 39, 2048-2057.

Pan, B., Lam, S.K., Mosier, A., Luo, Y., Chen, D. 2016. Ammonia volatilization from synthetic fertilizers and its mitigation strategies: A global synthesis. Agr Ecosyst Environ. 232, 283-289.

Pretty, J. 2018. Intensification for redesigned and sustainable agricultural systems. Science. 362, eaav0294. 
Rose, T. J., Wood, R. H., Rose, M. T., Van Zwieten, L. 2018. A re-evaluation of the agronomic effectiveness of the nitrification inhibitors DCD and DMPP and the urease inhibitor NBPT. Agr Ecosyst Environ. 252, 69-73.

Salazar, F., Martinez-Lagos, J., Alfaro, M., Misselbrook, T. 2012. Ammonia emissions from urea application to permanent pasture on volcanic soil. Atmos Environ. 61, 395-399.

Sommer S.G., Schjoerring J.K., Denmead, O.T. 2004. Ammonia emission from mineral fertilizers and fertilized crops. Adv Agron. 82, 557-622.

Stokstad, E. 2014. Ammonia pollution from farming may exact hefty health costs. Science. 343, pp. 238.

Subbarao, G.V., Nakahara, K., Hurtado, M.P., Ono, H., Moreta, D.E., Salcedo, A.F., Ito, O. 2009. Evidence for biological nitrification inhibition in Brachiaria pastures. P Natl A Sci. 106, 17302-17307.

Tzemi, D., Breen, J. 2019. Reducing greenhouse gas emissions through the use of urease inhibitors: A farm level analysis. Ecol Model. 394, 18-26.

van der Weerden, T. J., Cox, N., Luo, J., Di, H. J., Podolyan, A., Phillips, R. L., Rys, G. 2016. Refining the New Zealand nitrous oxide emission factor for urea fertiliser and farm dairy effluent. Agr Ecosyst Environ. 222, 133137.

Wang, Y., Guo, J., Vogt, R.D., Mulder, J., Wang, J., Zhang, X. 2018. Soil pH as the chief modifier for regional nitrous oxide emissions: New evidence and implications for global estimates and mitigation. Glob Change Biol. 24, e617-e626.

Wang, Y., Ying, H., Ying, Y., Zhen, H., Cui, Z. 2019. Estimating soil nitrate leaching of nitrogen fertilizer from global meta-analysis. Sci Total Environ. 657, 96-102. 


\section{Figures Subtitles}

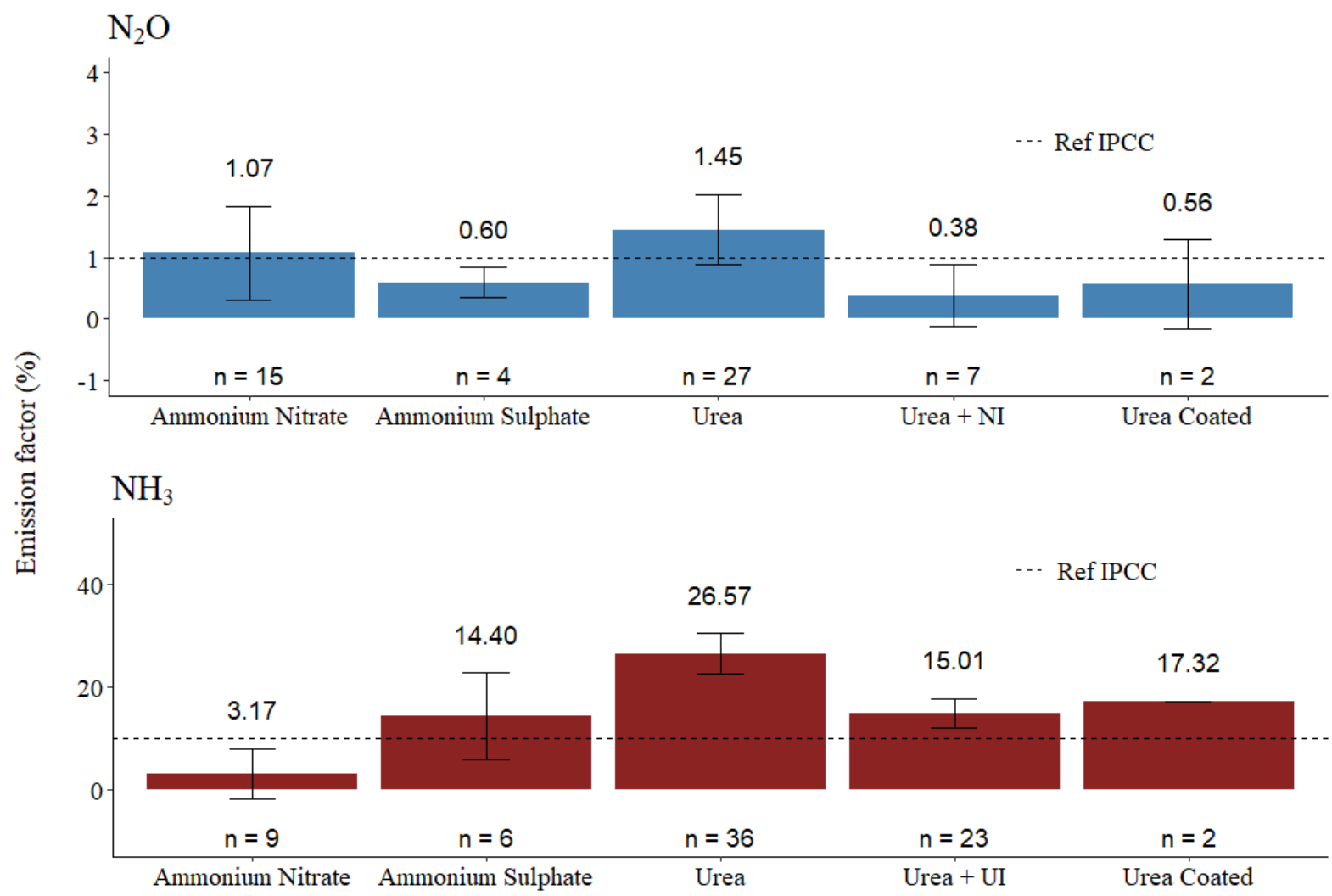

Figure 1. Emission factors for nitrous oxide and ammonia emissions, by fertiliser type. The dashed horizontal line marks the IPCC Tier 1 Default value for $\mathrm{N}_{2} \mathrm{O}(1 \%)$ and $\mathrm{NH}_{3}(11 \%)$. The error bars represent the $95 \%$ confidence interval. Urea+NI: urea applied with nitrification inhibitor; Urea+UI: urea applied with urease inhibitor. The " $n$ " represents the number of experiments. 


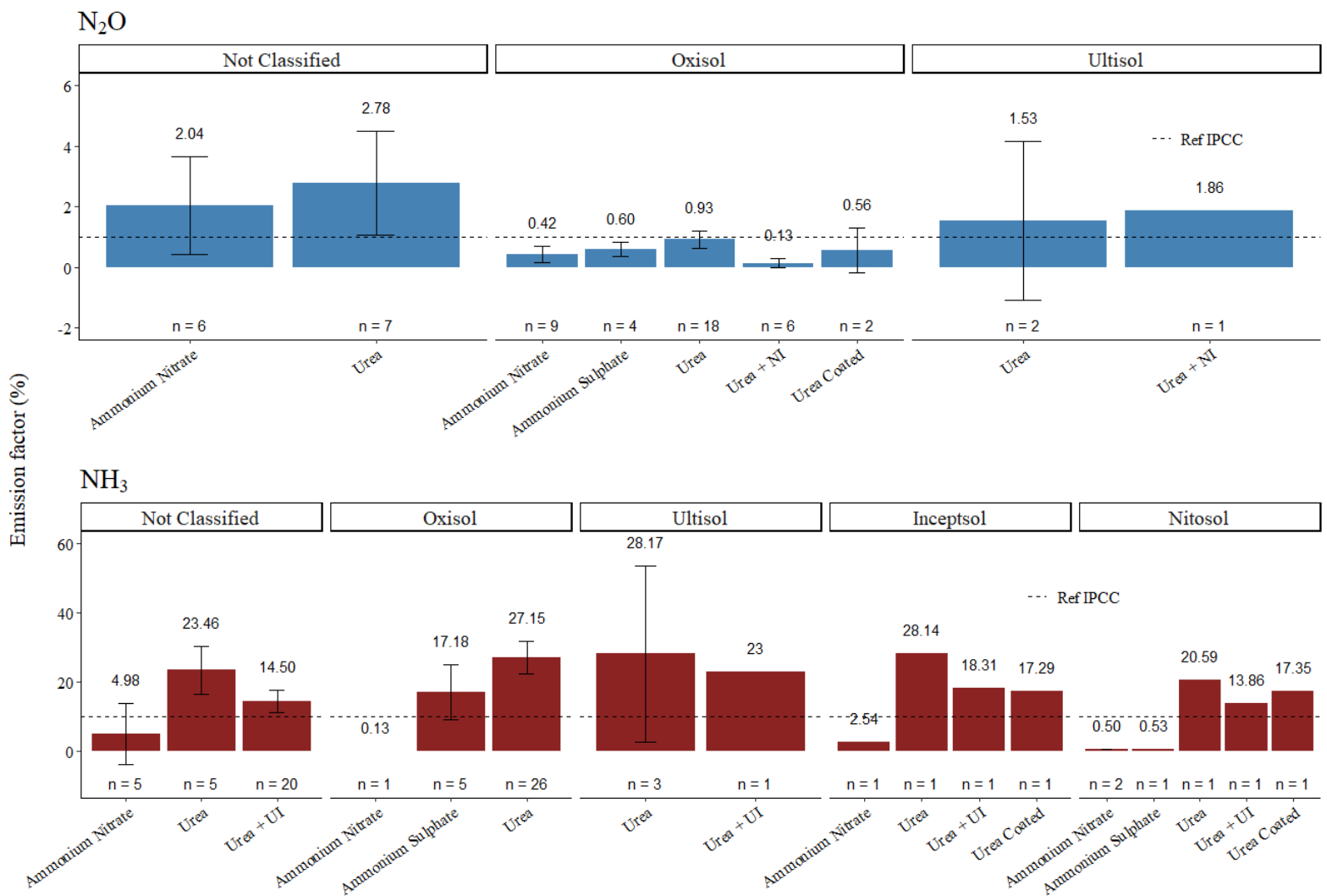

Figure 2. Emission factors for nitrous oxide and ammonia, by fertiliser and soil order. The error bars represent the $95 \%$ confidence interval. The horizontal dashed line marks the IPCC default value for $\mathrm{N}_{2} \mathrm{O}(1 \%)$ and $\mathrm{NH}_{3}(11 \%)$. Urea+NI: urea applied with nitrification inhibitor; Urea+UI: urea applied with urease inhibitor. The " $n$ " represents the number of experiments. 


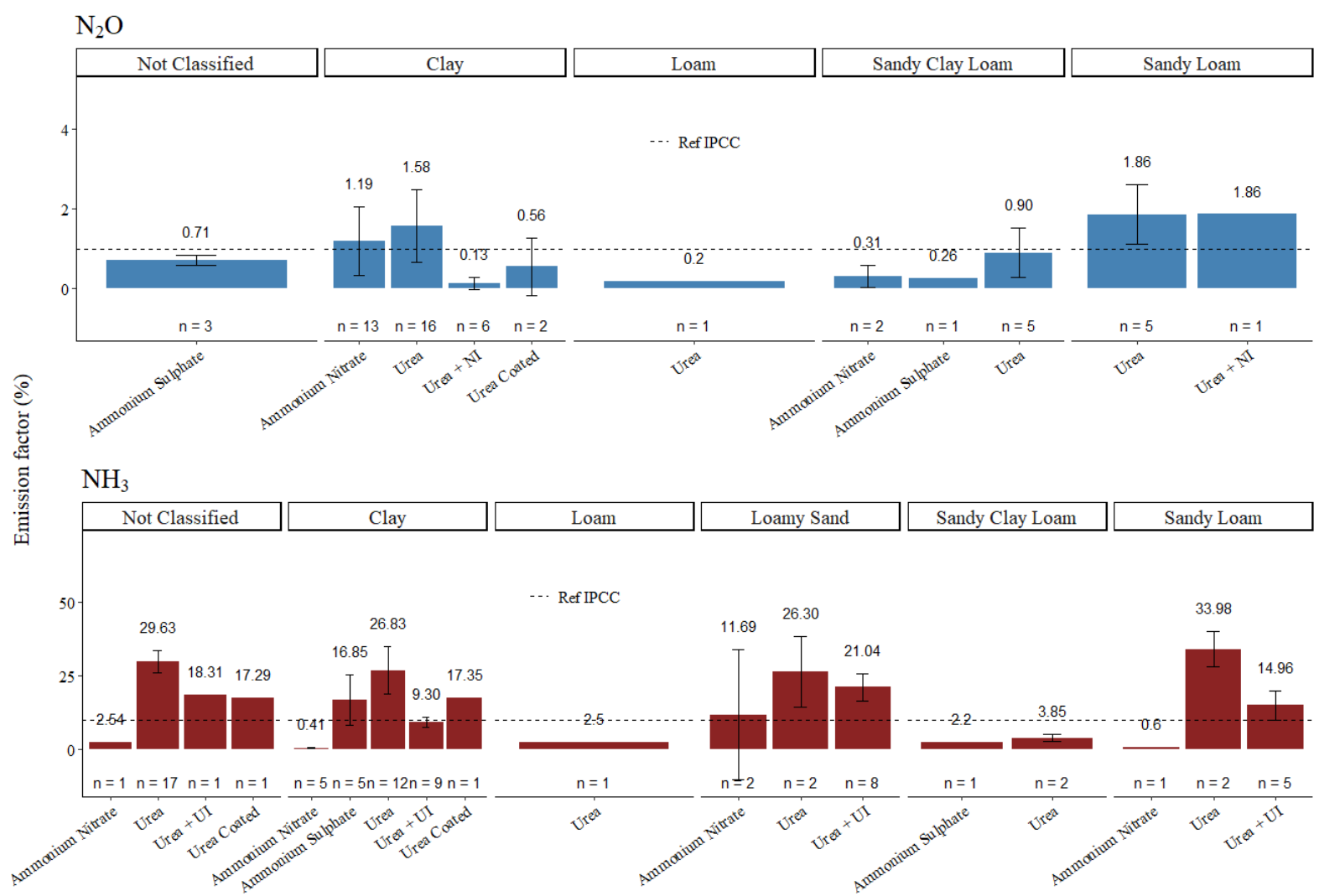

Figure 3. Emission factors for nitrous oxide and ammonia, by fertiliser type and soil texture. The bars represent the $95 \%$ confidence interval. The dashed horizontal line marks the IPCC default value for $\mathrm{N}_{2} \mathrm{O}(1 \%)$ and $\mathrm{NH}_{3}(11 \%)$. Urea+NI: urea applied with nitrification inhibitor; Urea+UI: urea applied with urease inhibitor. The " $n$ " represents the number of experiments. 


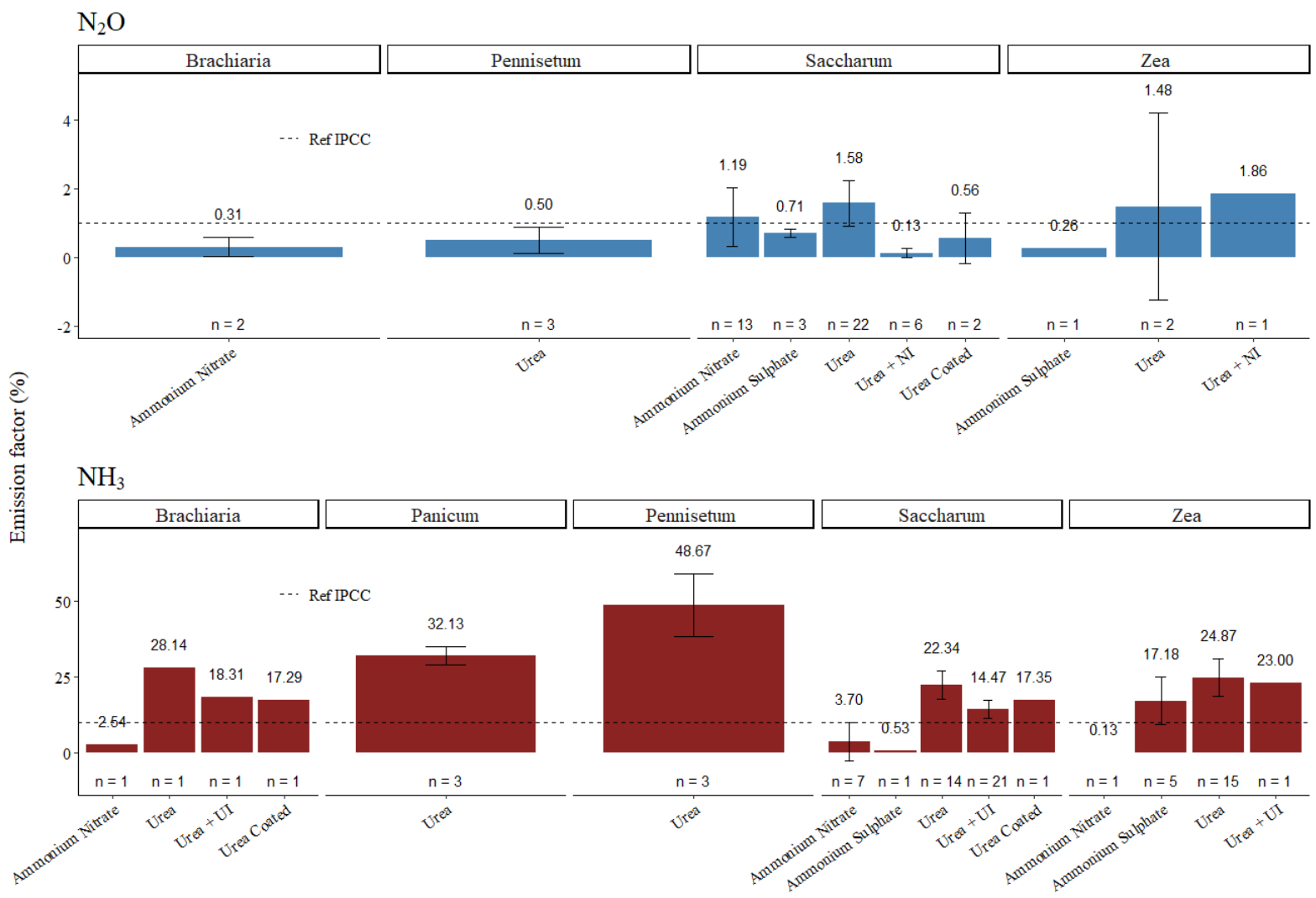

Figure 4. Emission factors for nitrous oxide and ammonia, by fertiliser type and land use. The error bars represent the $95 \%$ confidence interval. The dashed horizontal line marks the IPCC default value for $\mathrm{N}_{2} \mathrm{O}(1 \%)$ and $\mathrm{NH}_{3}(11 \%)$. Urea+NI: urea applied with nitrification inhibitor; Urea+UI: urea applied with urease inhibitor. The " $n$ " represents the number of experiments. 

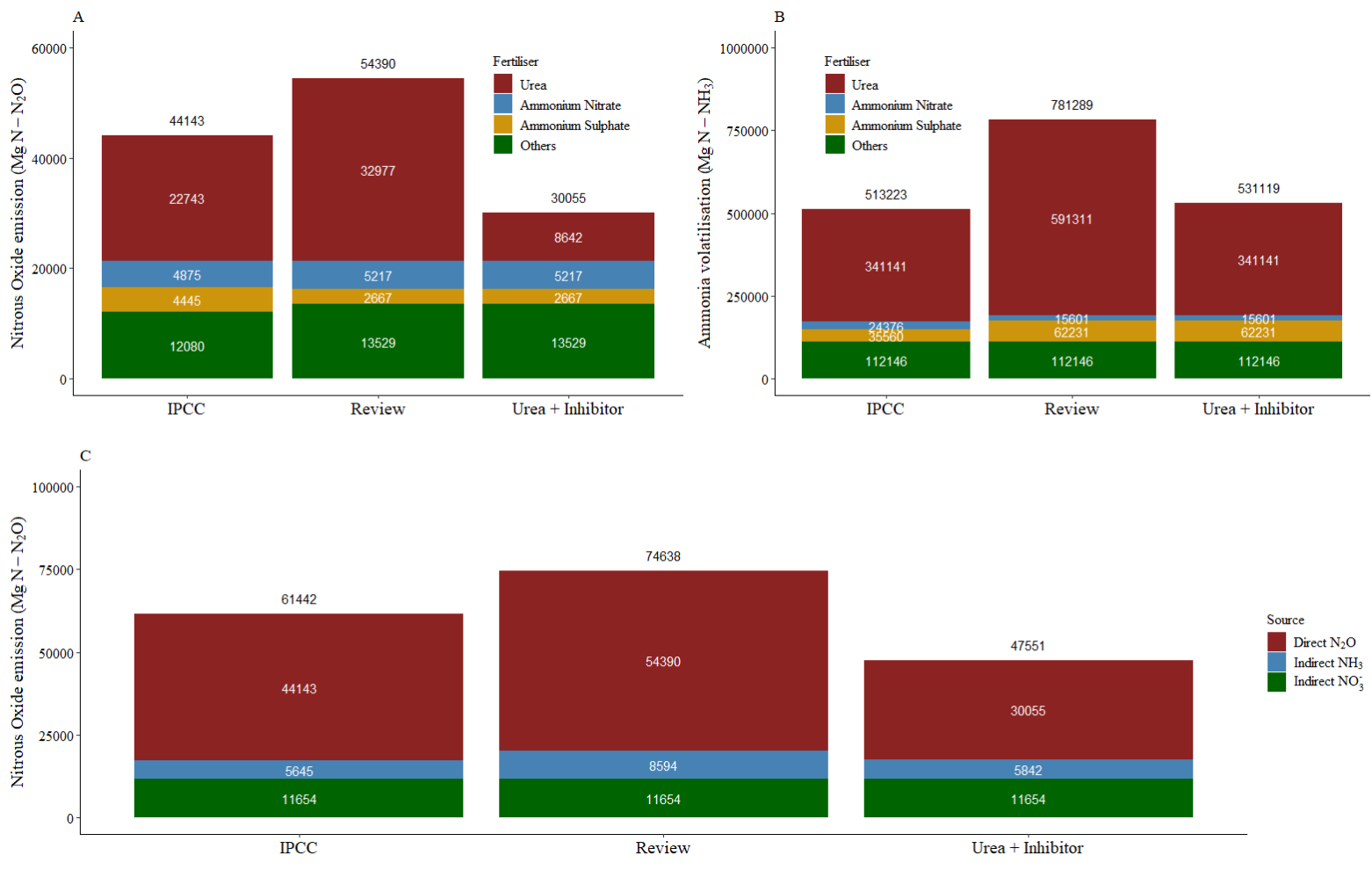

Figure 5 - Final Brazilian $\mathrm{N}_{2} \mathrm{O}$ budget for nitrogen fertiliser application in 3 different scenarios: (i) using the Tier 1 IPCC default values (IPCC); (ii) using the reviewed emission factors generated by this study (Review); and (iii) using the reviewed emission factors, considering urea being applied with nitrification and urease inhibitors (Urea + inhibitor). A: Direct nitrous oxide emission $(\mathrm{Mg})$; $\mathrm{B}$ : ammonia volatilisation $(\mathrm{Mg})$; $\mathrm{C}$ : Total nitrous oxide budget $(\mathrm{Mg})$ summing direct and indirect sources (from $\mathrm{NH}_{3}$ volatilisation and $\mathrm{NO}_{3}{ }^{-}$leaching) of $\mathrm{N}_{2} \mathrm{O}$. 